\title{
Sustainable Tourism Development: the Adaptation and Resilience of the Rural Communities in (the Tourist Villages of) Karimunjawa, Central Java
}

\author{
Budi Setiawan ${ }^{* 1,}{ }^{2}$, R. Rijanta ${ }^{2}$, M. Baiquni ${ }^{2,3}$ \\ ${ }^{1}$ Faculty of Social Science, Muhammadiyah University of Purworejo, Purworejo, Indonesia \\ ${ }^{2}$ Faculty of Geography, Gadjah Mada University, Yogyakarta, Indonesia \\ ${ }^{3}$ Center for Tourism Studies, Gadjah Mada University, Yogyakarta, Indonesia \\ ${ }^{*}$ Corresponding Author (e-mail: budi_setiawan@mail.ugm.ac.id)
}

Received: 09 November 2017/Accepted: 23 December 2017/ Published: 31 December 2017

\begin{abstract}
From 2009 to 2015, the growth of tourism in the tourist villages (desa wisata) of Karimunjawa underwent rapid progress. However, the level of poverty in Karimunjawa remained high. Nevertheless, the involvement of rural people in the sustainable development of tourism has received only limited discussion. Therefore, this article discusses the rural communities' adaptation and resilience in Karimunjawa with the support of sustainable development planning in tourist villages. It covers the background of sustainable development, the elements of the communities' adaptive capacity and resilience, and the role of the regional government. Empirical evidence of variations in the capacity to respond to changes of socioeconomic and ecological environments due to tourism development is presented. In addition, a case study is used in this article to describe how the people learned from their experience, knowledge, and past efforts. To obtain the necessary information, in-depth interviews were conducted with a number of key informants in the tourist villages of Karimunjawa, which were selected via purposive and snowball sampling. The results of the research show that social resilience will increase among those communities that are capable of accessing flexible social networks. These social networks are practical tools that open up the dissemination of new information and knowledge. This is a key element for a stronger process of transformation. Furthermore, communities that have capital and financial access as well as skills will also be capable of adaptation to the transformation process.
\end{abstract}

Keywords: sustainable tourism development; tourism; tourist village; adaptation; resilience; Karimunjawa.

\begin{abstract}
Abstrak. Dalam kurun waktu tujuh tahun (2009-2015), pertumbuhan pariwisata di desa wisata Karimunjawa mengalami kemajuan pesat. Namun angka kemiskinan di Karimunjawa cukup tinggi. Artikel ini membahas adaptasi dan ketahanan masyarakat pedesaan di Karimunjawa dengan dukungan perencanaan pembangunan berkelanjutan di desa-desa wisata. Ini mencakup latar belakang pembangunan berkelanjutan, elemen kapasitas adaptasi dan ketahanan masyarakat serta peran pemerintah daerah. Makalah ini menyajikan bukti empiris dari variasi dalam jalur jalan menuju kapasitas merespon perubahan lingkungan sosial ekonomi dan ekologi dari adanya pengembangan pariwisata. Metode studi kasus digunakan dalam artikel ini untuk menggali informasi tentang bagaimana orang belajar dari pengalaman, pengetahuan dan usaha masa lalu mereka. Wawancara mendalam dilakukan dengan sejumlah informan kunci di desa wisata Karimunjawa yang dipilih dari sampel purposive dan snowballing. Makalah ini menunjukkan bahwa ketahanan sosial akan meningkat pada komunitas yang mampu meng-akses jejaring sosial yang luwes. Jejaring tersebut menjadi alat praktis sebagai penyebaran informasi dan pengetahuan baru. Hal ini menjadi elemen kunci bagi menguatnya proses transformasi. Disisi lain, komunitas masyarakat yang memiliki modal dan akses keuangan serta keterampilan juga akan mampu beradaptasi dengan baik dengan proses transformasi.
\end{abstract}

Kata kunci: pengembangan pariwisata berkelanjutan; pariwisata; desa wisata; adaptasi; ketahanan; Karimunjawa. 


\section{Introduction}

Indonesia is still a largely rural country Administratively, there are 70,390 villages in Indonesia and 8,083 kelurahan (an administrative unit analogous to a village) in municipalities (Sari, 2016). Up until 2015, the proportion of the Indonesian population living in villages was considerably greater than that of those living in municipalities. Out of a population of 255 million, 57 percent were residing and earning their living in villages, and the remaining 43 percent were living in municipalities as permanent or temporary residents. Furthermore, according to the data from the BPS (2015), 10.96\% (27.73 million people) of the population in Indonesia were living in poverty, and approximately $62.65 \%$ of these were to be found in the villages (BPS, 2015).

One effort in rural development is the development of tourism in villages. A rapidly developing phenomenon, tourism has become one of the biggest industries in the world (Neto, 2003). It is considered to have great potential for socioeconomic development and the regeneration of rural areas, particularly those that are affected by the decline in traditional agricultural activity or that are marginal remote rural areas and therefore are regarded as having a unique life and culture (Urry, 2002). Tourism has become an increasingly popular component of development strategies in many backward regions, with the potential to improve the local economy and alleviate poverty (Muganda et al., 2010). For this reason, tourism development has been encouraged as a development strategy of many countries (Ca'noves et al., 2004; Hall and Jenkins, 1998; Long and Lane, 2000; MacDonald and Jolliffe, 2003; OECD, 1994) and in developing nations (Briedenhann and Wickens, 2004; Hall, 2004; Kinsley, 2000).

The major impact of tourism is perceived only by some people who benefit from its advantages, but others donotreceivethebenefits of tourism development owing to limitations in capital, business skills, and connections (Yang, 2015). The people in (tourist) villages are most vulnerable to economic turbulence and environmental damage, which can disrupt the people's livelihood and welfare. Livelihood adaptation and the strategies of rural people have been studied (see Dewi et al., 2005; Euler et al., 2017; Harini et al., 2017; Mahdi et al., 2008; Ritohardoyo, 2004; Widianingsih et al., 2016; Wijayanti et al., 2016forest dependence, and welfare in 73 villages. Village economic options, forest cover, and land suitability for agriculture and forestry are determining factors of people's well-being. Increased accessibility to markets and deforestation are strongly associated with economic diversity at the village level. Increased economic diversity, larger areas of forests, more intensive land use, higher endowments of agricultural land and forest, and higher village population are related to increased well-being. Oil palm is one of the most rapidly expanding crops throughout the humid tropics. In Indonesia, the expansion is largely driven by smallholder farmers. While recent research has studied effects for the environment and climate change, socioeconomic impacts in the small farm sector have hardly been analyzed. Here, we address this research gap by analyzing effects of oil palm adoption on farm household living standards and nutrition in Sumatra. Using survey data and econometric models, we estimate average impacts, impact pathways, and impact heterogeneity. Results show that oil palm adoption improves household living standards and nutrition. Mean impacts on food and non-food expenditures, as well as on calorie consumption and dietary quality, are all positive and significant. A sizeable part of the total effects is attributable to oil palm adopters expanding their farm size rather than realizing higher profits per hectare. Oil palm has lower labor requirements than alternative crops (especially rubber), but specific studies on rural communities are limited.

Nowadays, in order to develop tourism in the global era, an understanding of the resilience of the social system of ecology is essential. Tourism is a good example of the complexity of the social system of ecology (Complex Social Ecology System-SES): This is because of the 
dependence of tourism on natural resources, in which there is an interrelationship of elements, such as economy, politics, psychology, anthropology and ecology, cross-cultural and cross-sectional factors, and international relations (Cochrane, 2010).

When a large-scale transformation is unavoidable in tourism development, there is a need for the tenacity of a system to carry out renewal and reorganization. In other words, people are capable of overcoming problems, and of adaptation and reorganization without compromising the provision of ecosystem services. Resilience is often associated with a variety of opportunities and economic options that can be used to maintain and encourage adaptation as well as learning (Thompson, 2016). Walker et al. (2004) define resilience as "the capacity for a system experiencing change to absorb disturbance and reorganize while maintaining its original function, structure, identity, and feedbacks". They further define adaptability as "the capacity of actors within a system to influence and manage resilience" (Walker et al., 2004). People's adaptation and resilience demonstrates the mobilization to utilize local resources to mitigate or adapt themselves to environmental pressure and related risks (Adger, 2000; Wilson, 2012). Nonetheless, the development of the capacity for adaptation through the participation of the local population will be curtailed when the people feel that their resources are limited for adaptation (Thompson, 2016).

In this research, we worked with the people who live in Karimunjawa village. The rural community in Karimunjawa lives in the small islands of the Karimunjawa region in the Java Sea. Besides having a high potential of marine resources, the small islands are extremely vulnerable to various disruptions of the ecological systems, as well as physical/ natural, ecological, sociocultural, and political disturbances (Rijanta, 2005). One of the high potential resources in an archipelago is the tourism sector (Baiquni et al., 2014). Indeed, as one of the tourist destinations, Karimunjawa experienced fairly high tourism growth at this time; yet, there is a significant number of poor people in Karimunjawa, so the resilience and adaptation of the local people will determine the sustainable growth of tourism in Karimunjawa.

The Indonesian government is currently focussing on the development of small islands as conservation areas in connection with the tourism industry. Within a period of seven years, tourism development in Karimunjawa village has undergone a considerable boost as is evident from the increased numbers of foreign and domestic tourists (TIC, 2016), and there has been a rapid growth in facilities for the tourism business (BPS, 2016). This article aims to describe the phenomenon of adaptation and social resilience in tourism-based villages by examining the advantages of the delineation of theresilience theory for tourism in Karimunjawa as a socio-ecological system. The aims of this research are firstly to test the effectiveness of the heuristic model of the adaptive cycle in analysing the tourism-based village context, and secondly, to test the heuristic benefit in the application of policies and actions that fulfill the needs of the local community and social learning, and further, to define the people's needs and sustainable tourism development. The remainder of this paper will present the methodology used, which is followed by the presentation and discussion of the results, and finally, the conclusions that can be drawn.

\section{Research Method}

\subsection{Study area}

The research was conducted in Karimunjawa subdistrict, which is one of the subdistricts in Jepara regency, Central Java. Geographically, Karimunjawa Island is located 45 nautical miles or about 83 kilometers northwest of Jepara, at a height of 0-605 meters above sea-level, at $5^{0} 40^{\prime} 39^{\prime \prime}-5^{0} 55^{\prime} 00^{\prime \prime}$ and $100^{\circ} 31^{\prime} 15^{\prime \prime}$ East Longitude, with an area of 169,800 ha consisting of a land area of 7,120 ha and a marine area of 162,680 ha (Setiawan et al., 2017). 


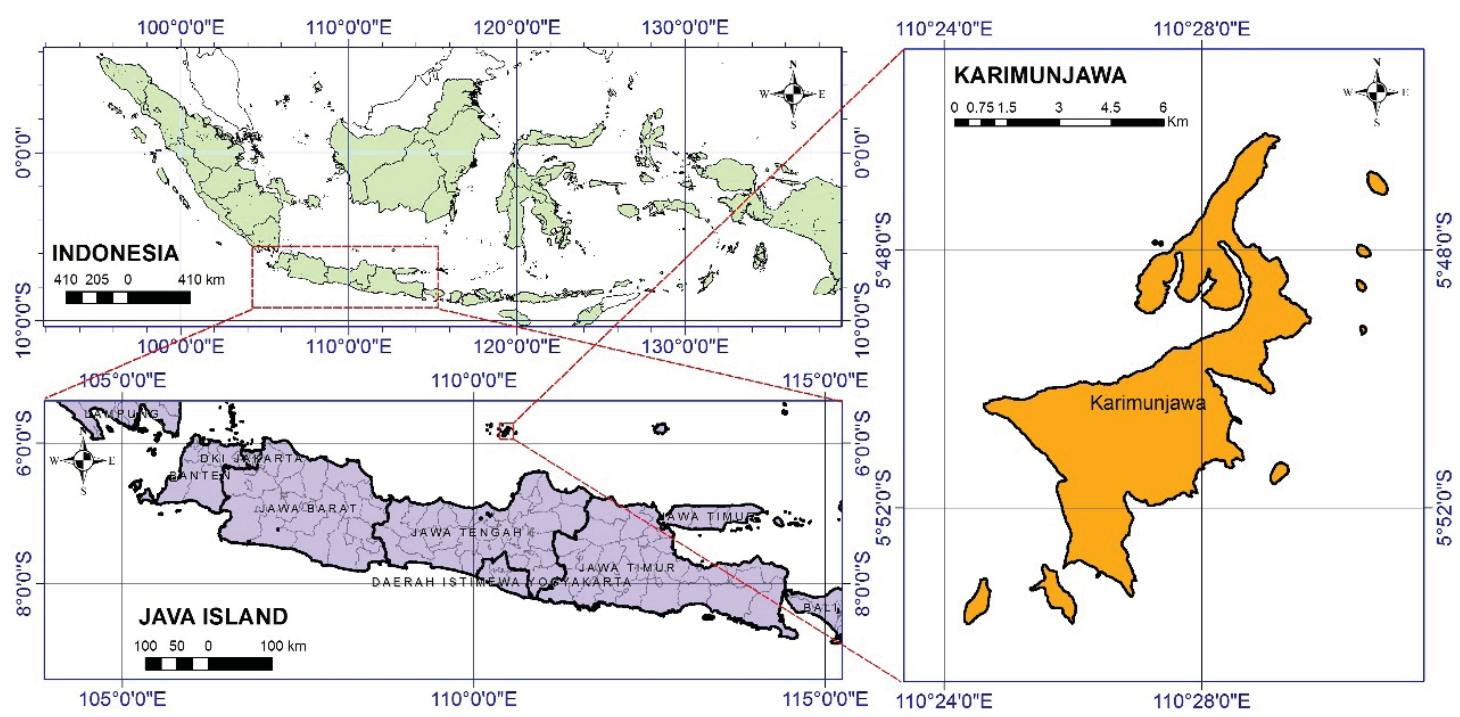

Figure 1. Study Area and Location of Karimunjawa.
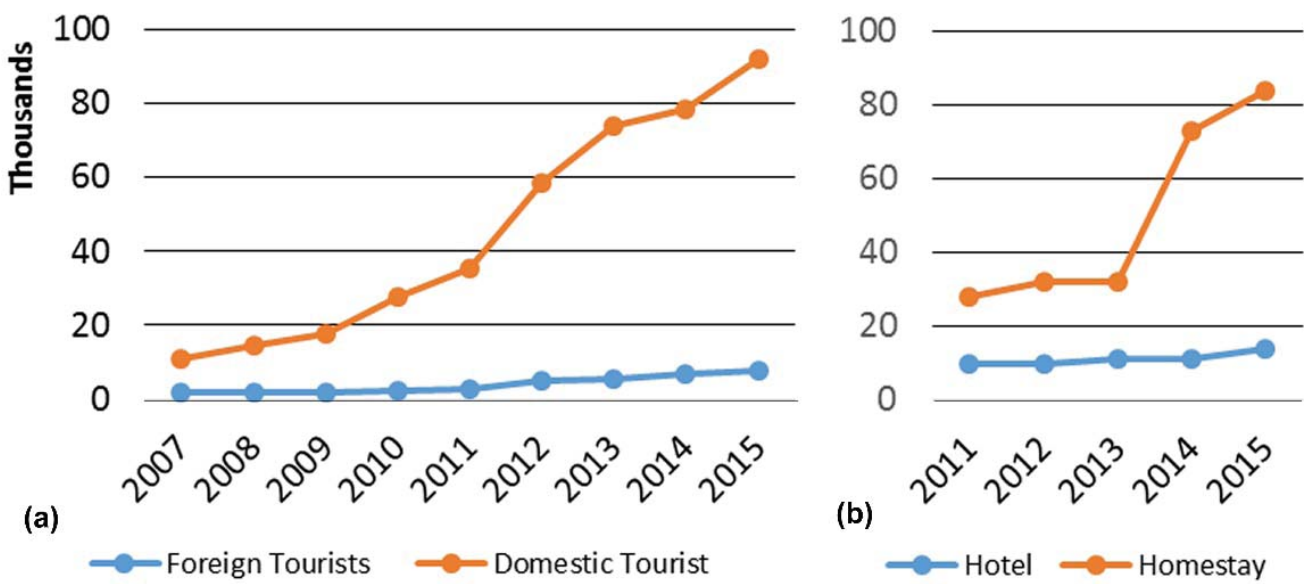

Figure 2. Tourism development in Karimunjawa. (a) Graphic of Tourist Visit; (b) Number of Hotels and Homestay in Karimunjawa (Setiawan et al., 2017).

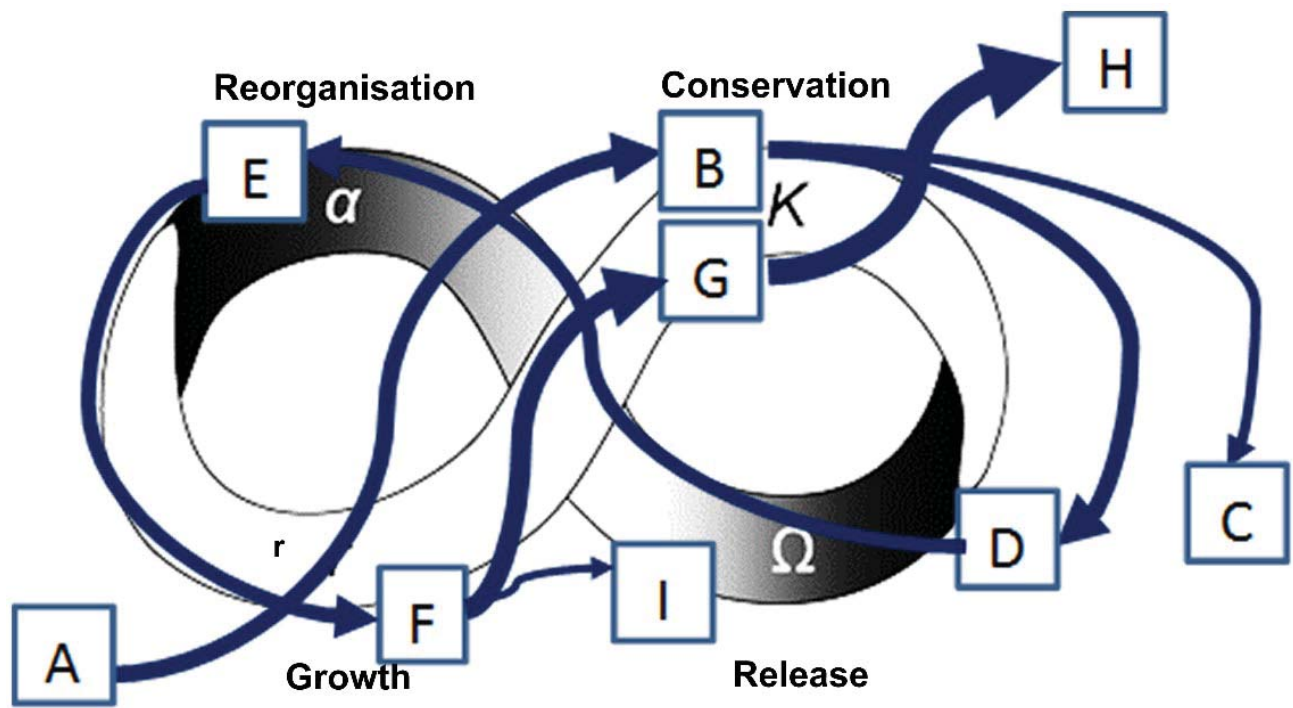

Figure 3. An adaptive cycle depicts the transition of Karimunjawa from dependence on agriculture and fisheries to tourism and service businesses (adapted from Holling \& Gunderson [2002]). 
In 2014, Karimunjawa subsdistrict had a population of 9,016 consisting of 4,547 men and 4,469 women. It was the most sparsely populated subdistrict in Jepara regency $(0.78 \%)$, which comprised 2,621 households, so that, on average, a household had 2-4 members. Karimunjawa village was the most densely populated, with 4,557 people or $50.54 \%$ of the total population in the subdistrict, whereas Nyamuk village was the most sparsely populated, with 551 people or $6.11 \%$. According to a report by the BPS (2016), the welfare level of Karimunjawa subdistrict was low: $32 \%$ of the households belonged to the category of prewelfare households, and $27 \%$ to the category of welfare 1 households (see Figure 2 in Setiawan et al., 2017).

The high poverty rate in Karimunjawa subdistrict runs parallel with the data on the low levels of education. Most of the people there are primary school leavers $(47.98 \%)$, and, in fact, a considerable number did not finish primary school education, i.e., 32.67\% (see Table 2 in Setiawan et al., 2017). Therefore, considering the high percentage of the productive age group, the quality of human resources in the subdistrict is arguably low. Most of the people in Karimunjawa (88.56\%) work in the informal sector, with the highest percentage working as fishermen $(59.53 \%)$, and as farmers $(19.32 \%)$ whereas others work as farm laborers, construction workers, artisans/ craftsmen, shopkeepers/tradesmen, breeders, and mechanics. Indeed, it is very difficult to distinguish between the communities of fishermen and farmers, and to classify them into two groups in terms of means of livelihood because, in reality, they are engaged in both spheres. At certain times, they cultivate the fields, but at other times, they also go fishing or manage inland fisheries (Setiawan et al., 2017).

\subsection{Data collection}

By adopting the case study method, we explored how the community bring with them their experience, knowledge, and efforts; this gradually enables them to increase their capacity for adaptation and resilience in order to improve their livelihood amidst the changes in the socioeconomic and ecological environment. In-depth interviews were conducted from April to December 2016 with five key persons, who were selected using the snowball sampling method. This technique is very appropriate in terms of effectiveness in obtaining the unit case in accordance with the expected criteria. The researcher makes initial contact with a small group of people relevant to the research topic and then uses this to establish contact with others so that a sampling frame is no longer needed in this method. However, the sample is not a random one, and therefore, the general picture of the population may not be well represented (Becker 1963 in Bryman, 2008). These key people represent the most capable people in the tourist village, as they were able to provide important data and information as individuals, households, and community members. These people were also partially undergoing the transformation process of adaptation and resilience.

Secondary data were obtained from official documents and from literature relating to the research questions. The secondary data are social economic level, demographics, and tourist visits. Library research was conducted to gather data from a number of references related to spatial planning, demography, tourism, etc.

\subsection{Data analysis}

Data from the in-depth interviews were organized, coded, and analysed utilizing the principles of content analysis (Krippendorff, 2004). Data analysis was conducted using the inductive approach and manual coding technique. The analysis process began with categorizing the indicators of transformation from which the community drew their experiences, knowledge, and efforts to minimize their vulnerability regarding tourism development. For the purpose of identification, respondent interviews result were coded as integer (INT). 


\section{Result and Discussion}

\subsection{Tourism in Karimunjawa}

One of the potential spheres for economic development on the island is tourism; this is the largest industry in the world and has been an integral component of the strategy for economic development in various countries. Tourism has the potential for yielding foreign exchange, attracting international investments, increasing tax revenues, and creating new opportunities for employment (Setiawan et al., 2017). Tourism visits to Karimunjawa Island by domestic and foreign tourists have significantly increased since 2007. In 2015, there were 7,579 foreign visitors to the island, and 84,536 domestic visitors, and this number has continued to increase in comparison with the numbers in the preceding years (TIC, 2016). Visits by domestic and foreign tourists increased in frequency by as much as $158 \%$ and $166 \%$ respectively compared with visits in 2007 (Figure 2a). This shows that there is considerable potential for tourism development in Karimunjawa. This potential is enhanced by the opening of a ferryboat crossing in Kendal seaport in addition to the one in Jepara seaport.

In Karimunjawa, there are about 38 destinations which appeal to both domestic and foreign tourists. The frequently visited destinations are the Shark Pond, snorkelling on Menjangan Island, several coasts areas (such as Barakuda, Batu Topeng, Nirwana, Ujung Gelam, Kemloko, Batu Putih, Batu Lawang, etc.) and nature trails in a mangrove forest.

Tourism development in Karimunjawa village is more noticeable than that in Kemujan village. This is because, besides being a village with a predominance of tourist destinations, Karimunjawa is the gateway for tourists to Karimunjawa Pier, which has encouraged the construction of facilities and infrastructure for tourists in the village. During the period 2011-2015, the growth of hotels, resorts, and homestay accommodation was remarkable, with an increase of $40 \%$ for hotels and resorts, and $56 \%$ for homestay accommodation (Figure $2 b)$.

\subsection{Adaptation and resilience of Karimunjawa communities \\ 3.2.1. Adaptive cycle}

The development of an adaptation curve for Karimunjawa uses the data from interviews with informants and archives. An adaptive cycle in Karimunjawa is presented in Figure 3. The period of Karimunjawa's dependence on natural resources, particularly the sea, from the 1900s to the 1970s is shown in Figure 3 with the curve from $\mathrm{A} \rightarrow \mathrm{B}$. During this period, the people were extremely dependent on marine resources bolstered by agriculture and forestry. The economic condition of dependence on natural resources was quite strong: catches of fish and several kinds of timber (Kalimasada, Dewadaru, and Setigi) were known as the region's first-rate products, while agriculture was developed in order to meet household needs (INT 3). The decline in fishery products as a result of climate change and the zoning system, and a decrease in timber production affected the socioeconomic conditions (Balai Taman Nasional Karimunjawa, 2004; Immawati et al., 2012). The threshold where this took place is represented by $B$, which is the accumulation phase at the adaptation curve marked by the decrease in the catches of fish. Respondents mentioned that the decline in fish production is caused by huge waves in Karimunjawa waters and the zoning of fishing.

The people of Karimunjawa depended on natural resources for the fulfilment of their basic needs. Historically, they were moulded into becoming coastal communities. Their earnings as fishermen fluctuated and were extremely dependent on natural phenomena. Fishermen generally catch fish using muroami, branjang, tonda fishing lines, edo fishing lines, and nets (Jumadi \& Kuswaji, 2005). It was this condition that caused demographic fluctuations up until the 1970s. The people of Karimunjawa were not really permanent 
residents who lived in the region continuously from generation to generation (INT 2). Rather, one generation came, and as they did not feel at ease with the dry, barren land and climate change, they decided to leave.

The management of the National Park relating to the consolidation of the region has been carried out by the restructuring of the zonation of the conservation of Karimunjawa National Park. The application of zonation or the boundary system/arrangement was not effective. Although many people knew about the zonation, there were still violations by individuals who entered the forbidden zones, and many of the boundary signs disappeared. This was because the dissemination of information did not reach the right target, including the District Office of Fisheries, which was in charge of issuing a fishing permit. Besides, other factors were responsible, such as the residents' knowledge about the importance of a nature reserve, and their financial difficulties in meeting their needs. The complaint often made by the fishermen was as follows: "I am obedient to the prohibition to catch fish in the zonation, but others are not" (INT 5).

$\mathrm{B} \rightarrow \mathrm{C}$ and $\mathrm{B} \rightarrow \mathrm{D}$ on the curve represent the first restoration phase. $\mathrm{B} \rightarrow \mathrm{C}$ shows the existence of a part of the population who decided not to remain in Karimunjawa, as they were not able to adapt to an economy that is dependent on natural resources, and so they decided to move and find work in other regions. $\mathrm{B} \rightarrow \mathrm{D}$ represents the residents who decided to remain in Karimunjawa, as they could adapt to the socioeconomic and ecological change, and to the shift in various forms of capital and resources in the community. $\mathrm{D} \rightarrow \mathrm{E}$ and $\mathrm{E} \rightarrow \mathrm{F}$ show the restructuring of various forms of capital in efforts to restore the economy. As testified by the respondents, tourism helps the emergence of the diversification of employment. The designation of Karimunjawa as a National Park restricts the fishing zone on the one hand, but on the other hand, it opens up a potential new economy, i.e., tourism. The line $\mathrm{F} \rightarrow$ I shows those who decided to hold out as traditional fishermen and subsistent farmers; these were mainly residents over the age of 50 .
Subsistent farmers are few in number, and there has been a decrease in agricultural and livestock production from year to year (INT 1). Thus, $\mathrm{F}$ in Figure 3 was the beginning of an important period in the history of Karimunjawa.

Since being designated as a National Park and tourist destination in the 1990s, Karimunjawa had been visited by tourists albeit not in great numbers. Not until 2011 was there a marked increase in the number of tourists coming to Karimunjawa, which coincided with the establishment of a cellular communication network (3G) in the region. The most probable cause of the growth of tourist visits is information that is scattered through the internet or on social media (INT 5). With the growth of tourism, Karimunjawa, as a tourist destination, has undergone a rapid change in connection with the development of facilities and infrastructure, which has made life easier for the population. Supporting infrastructure continues to be developed, including amongst others, the public supply of electricity, the optic fibre network, the means of sea transportation, and highways (INT 5). Life in Karimunjawa has undergone a period of transition towards an orientation to easier living. However, many residents say that they feel they have lost "their small villages" as if they were simply enjoying the darkness and quiet of the island (INT 2), saying, for example, "Karimun is now different, it was not as crowded as it is now ..... and we feel that the change has happened very quickly" (INT 2 ). It is now a region with the power to attract people from other areas.

Tourism started in the 1990s though on a small scale. During this period, Karimunjawa began to be marketed as a tourist attraction. The consequence of the promotion of the region was the introduction of facilities as attractions that played an outstanding role, and the economic base began to shift to the service sector. Therefore, phases $\mathrm{F} \rightarrow \mathrm{G} \rightarrow \mathrm{H}$ (Figure 3.) were fast phases; they were the phases in which the service-based economy began to expand and grow rapidly at the beginning of the 2000s, in conjunction with the opening of the crossing route from Semarang to Karimunjawa and the increasing number of 
visitors. Tourism has contributed greatly to the people of Karimunjawa in ways that ensure they are no longer dependent on the fisheries and agricultural sectors. This is evident in the improved economy of those people who are able to build or repair their homestay facilities (INT 3). One informant from a poor household testified that she benefits from tourism-related activities, as she can work as a temporary laborer for a homestay accommodation as a laundress and cook, and her daughter also assists her in the job. For residents who have lived there for a long period, there are more jobs available, mostly in the service sector, though for them, these are merely additional jobs.

$\mathrm{G} \rightarrow \mathrm{F}$ in Figure 3 represents the accelerated growth, especially the dissemination of information about the charm and attractiveness of the region in the social media and the ease of the routine crossing from Jepara by the Siginjai ferry-boat and the Bahari Express Ship. This period was also marked by the establishment of Karimunjawa as the foremost destination in Central Java and the growth of infrastructure for tourism. The government also responded by setting up training courses for the management of homestay accommodation, constructing the Legon Bajak port with a greater capacity and a 24-hour electricity network starting from June 2016. Respondents questioned the course of development of Karimunjawa, i.e., whether it will be on a par with other destinations in Bali or Lombok, or whether it will go through a phase of deterioration. A range of possibilities is open: it is possible that Karimunjawa will approach a phase of rejuvenation/revitalization or a phase of sustainable accumulation characterized by a period of economic stagnation.

\subsubsection{Integration of Vulnerability, Adaptive Capacity, and Resilience}

Karimunjawa has undergone a transformation from a dependence on fishery and agricultural resources to the service sector of tourism. The growth of tourism in this region has been taking place for the past several decades, and in various ways, but people are still uncertain about the kind of development they want and need. The presence of investors and outsiders is greatly beneficial, but it also causes social problems, such as the loss of the sense of togetherness, the weakening of the conservation of nature, and the historical orientation of the past of Karimunjawa. The main problem faced by the region seems to be how to achieve a proper balance between developing tourism and maintaining the good local values in relation to the sociocultural factor as well as the local economic resources. It is probable that in the near future, the adaptation phase will enter a restructuring phase comprising aspects such as the change of land function and the increasing socioeconomic imbalance. This can be seen in some of the land owned by local residents, who took advantage of the offer of the sale and the control of land by investors.

The rapid growth of Karimunjawa seems to be oriented to dependence on the tourism sector, which will affect the people's capacity for adaptation and resilience in facing the transition to the transformation and facing the future. The people strive to protect the activities that they deem beneficial for human welfare and ecological sustainability, but these activities are under threat from contemporary pressure or from a future related to socioeconomic and ecological changes. A key concept for evaluating the adaptation phase in the transformation phase is identifying the existing vulnerability due to social, economic, and ecological changes. On the other hand, socio-economic and ecological changes can be a source of future resilience and opportunities. This is to encourage the community's capacity for adaptation, which can be used to tackle future transitions. This relationship is summarized in Table 1: the indicators used are those that are relevant for identification by the respondents, which include social capital, natural resources capital, financial capital, physical capital, and human resource capital. The sources of vulnerability, potential sources of resilience, and opportunities to build the capacity for adaptation come from the respondents' perspectives, from policies that have actually been adopted in the community, and from data interpretation. 
Table 1. Implication of Transformation for People's Resilience and Capacity for Adaptation.

\begin{tabular}{|c|c|c|c|}
\hline Indicators & Source of Vulnerability & Adaptive Capacity & Potential Source of Resilience \\
\hline Social Capital & $\begin{array}{l}\text { - Reduced networks and } \\
\text { social support related to } \\
\text { development and change in } \\
\text { land use } \\
\text { - Weak arrangement in } \\
\text { networks of grassroots } \\
\text { or institutions (such as } \\
\text { cooperatives) }\end{array}$ & $\begin{array}{l}\text { - Opening access to } \\
\text { external networks and } \\
\text { capital } \\
\text { - Opening access to } \\
\text { learning networks in } \\
\text { groups }\end{array}$ & $\begin{array}{l}\text { - Increased variety in social } \\
\text { structure and labor force } \\
\text { - Increased connection in exist- } \\
\text { ing social networks } \\
\text { - Increased transfer of knowledge } \\
\text { as a result of social networks } \\
\text { and technology } \\
\text { - Emergence of thematic commu- } \\
\text { nities for economic activity and } \\
\text { the environment } \\
-\quad \text { Stability of job opportunities in } \\
\text { the economic sector }\end{array}$ \\
\hline $\begin{array}{l}\text { Financial Cap- } \\
\text { ital }\end{array}$ & $\begin{array}{l}\text { - Decline of fisheries and } \\
\text { agriculture } \\
\text { - Poverty } \\
\text { - Change of orientation from } \\
\text { production to service } \\
\text { - Low wages in the service } \\
\text { sector } \\
\text { - Instability of potential mar- } \\
\text { kets of tourism } \\
\text { - Restricted access to health } \\
\text { facilities and education } \\
\text { - Possession of property by } \\
\text { investors }\end{array}$ & $\begin{array}{l}\text { - Investment by local } \\
\text { community in service } \\
\text { sector (tourism) } \\
\text { - Work in tourism as } \\
\text { side job for household } \\
\text { heads } \\
\text { - Aspects of courtesy, } \\
\text { good manners, reli- } \\
\text { gious values } \\
\text { - Growth of assets } \\
\text { with new property } \\
\text { (homestay accommo- } \\
\text { dations) }\end{array}$ & $\begin{array}{l}\text { - Diversity of products unaffect- } \\
\text { ed by seasons } \\
\text { - Development of new forms of } \\
\text { business investment to bolster } \\
\text { tourism } \\
\text { - Environmental awareness and } \\
\text { health security } \\
\text { - Programs of improved quality } \\
\text { and service in health and edu- } \\
\text { cation } \\
\text { - Improved access to roads, com- } \\
\text { munications, and markets }\end{array}$ \\
\hline $\begin{array}{l}\text { Natural Cap- } \\
\text { ital }\end{array}$ & $\begin{array}{l}\text { - Reduced access to public } \\
\text { areas (due to increased } \\
\text { private areas for hotels, } \\
\text { resorts etc.) } \\
\text { - Threat of water supply, } \\
\text { floods }\end{array}$ & $\begin{array}{l}\text { Maintaining the social } \\
\text { environment individu- } \\
\text { ally or in groups (e.g., } \\
\text { cleaning activity on } \\
\text { Fridays) }\end{array}$ & $\begin{array}{l}\text { - Potential natural tourism } \\
\text { - } \quad \text { Diversity of natural tourism }\end{array}$ \\
\hline $\begin{array}{l}\text { Human Cap- } \\
\text { ital }\end{array}$ & 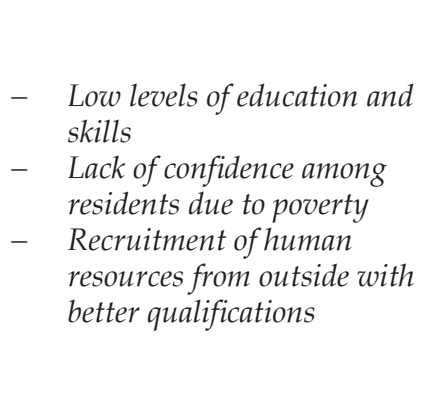 & $\begin{array}{l}\text { - Investment in human } \\
\text { resources } \\
\text { - Interaction of thematic } \\
\text { environments as infor- } \\
\text { mal and formal social } \\
\text { institutions } \\
\text { - Access to training/ } \\
\text { education on improved } \\
\text { capacity }\end{array}$ & $\begin{array}{l}\text { - Upgraded human capital } \\
\text { through learning opportunities } \\
\text { - New knowledge and skills from } \\
\text { social networks } \\
\text { - People's awareness and positive } \\
\text { acts for the future } \\
\text { - Increased number of human } \\
\text { resources involved in several } \\
\text { communities related to tourism } \\
\text { and the social and ecological } \\
\text { systems }\end{array}$ \\
\hline
\end{tabular}

\subsubsection{Discussion}

The change towards the economic development of tourism requires the people of Karimunjawa to be adaptable. Our findings reveal the experiences of past changes and memories experienced by the people of Karimunjawa. Slootweg et al. (2001) and William and Schirmer (2012) mention that local people tend to rely on the "feel" of change experiences and take action to overcome trends they feel and experience. The local people of Karimunjawa are able to sense the periods of socioeconomic and ecological changes that occur, but the response to change varies depending on individual circumstances and perceptions. As Rawluk and Curtis (2016) comment, past experience and memory of change may show an adaptive cycle in rural and regional societies. The adaptive cycle is a useful aid in visualizing, organizing, and then comparing the discourse of landscape change. Different experiences among residents in Karimunjawa cause differences in their future opportunities for changes in the socio-economic and ecological environment. In addition, differences in the social, demographic, and economic backgrounds cause differences in people's adaptive response. Besides social 
networks, the possession of capital and financial access is very influential in adaptation. Modification in the means of livelihood and the introduction of new investment prove the people's capacity for adaptation to deal with the process of transformation. The emergence of communities of a thematic environment is beneficial for some people to learn from others so that they can improve their ability to collaborate in order to meet their household needs and the needs of the community. This readiness proves the adaptation process and social learning from new and flexible social networks, which have become practical tools to find a sustainable means of livelihood.

We believe that Karimunjawa has undergone a transformational transition from a dependence on fishery and agricultural resources to the tourism services sector. However, we also found that some people still do not understand what kind of development they want and need in the changing socioeconomic and ecological environment of tourism development. Informants' or local communities' view of the growth of tourism in Karimunjawa as providing either opportunities or threats can be described as a reaction to the perceived experience. Thus, there are various responses to the growth of tourism in Karimunjawa. For instance, some people see the opportunity for this socio-economic environment as being only temporary, so they take advantage of it by selling their previously worthless assets. On the other hand, there is a group of people who prefer to consider that this transition process will be sustained and will change the local economy to bring many economic opportunities. We anticipate that the main problem Karimunjawa will face is finding a balance between cultivating a tourism business and local values both in terms of sociocultural as well as local economic resources.

The Karimunjawa community has adaptively adopted cycles in response to changes in the socio-economic and ecological environment. Adoption of the adaptive cycle in Karimunjawa society has proven to be very useful as a tool for assessing the resilience of the community and as a tool for increasing the knowledge and awareness of the individual towards local actors in Karimunjawa. The adaptation response of Karimunjawa society is determined by the mastery of social, economic, and natural capital. Salvia and Quaranta (2015) used an analysis of the dynamics of social, economic, and natural capital as key to interpreting the various phases of the adaptive cycle in a changing agricultural system in the Basilicata region of Southern Italy. This analysis is also used to describe the relationship between sustainability and sustainable development in Karimunjawa. The growth phase aimed at the tourism sector in Karimunjawa will affect adaptability and community resilience. People's resilience aims to protect the perceived activities of the population for the benefit of human well-being and ecological sustainability, but it is threatened by contemporary or future pressures associated with socioeconomic and ecological environmental change. Social resilience provides an iterative framework for addressing complex social interactions. Adger (2000) reveals that this relates to how social groups adapt to environmental change and shows how societies can survive and recover from stress, such as environmental change or social, economic, or political upheaval.

We find increased social resilience in communities capable of accessing social networks. They have the flexibility in accessing social networks and are open to new information and knowledge especially in responding to environmental change. Community groups conduct resource management in response to changes in the socio-economic and ecological environment. The conceptualisation of local resource management is a response to environmental change, which is achieved by staying in the environment and interpreting the meaning of the environmental change. In Karimunjawa, some residents make a living as fishermen $(80 \%)$. Their history characterizes the sea as the main space for life, especially their life on the coast, by their use of biological resources. Indeed, local people's dependence on resources was disclosed by Perz et al. (2012). The decreasing access to resources can signal a reduction in community resilience. However, 
the conditions are somewhat different from Karimunjawa, where the decline in access to natural resources has been followed by people effecting changes in their livelihoods to respond to the decline in access.

\section{Conclusions}

The change to the economic development of tourism requires the people of Karimunjawa to be adaptable. However, differences in the social, demographic, and economic backgrounds lead to differences in people's adaptive response. Besides social networks, the possession of capital and financial access are very influential factors in adaptation. Modification in the means of livelihood and the introduction of new investment demonstrates the people's capacity for adaptation to deal with the process of transformation. The emergence of communities of thematic environments is beneficial for some people, allowing them to learn from others so that they can improve their ability to collaborate in order to meet their household needs and the needs of the community. This readiness proves the adaptation process and social learning from new and flexible social networks, which have become practical tools to find sustainable means of livelihood.

This article has contributed to supplementing the existing literature in sustainable tourism development in terms of social adaptation and resilience in the dynamics of an agriculture-based village and a fishery village change to a tourist village.. The findings can be used as a key elucidation, and serve to offer different perspectives in various situations, including economic, environmental, and sociocultural aspects. Research in the future can be directed to the formation of a comprehensive model for sustainable tourism development in (tourist) villages made up of the elements of the resilience of the local community. This should add a new approach to the planning of rural tourism, combining the concept of traditional sustainability, and contribute more new work on social resilience. This sustainable tourism approach proves to be more effective when implemented among people who are very sensitive to the global environmental and economic changes like village-based tourist communities in coastal areas, small islands, and hilly terrains.

At least three recommendations for public policies can be made from the synthesis of adaptation and resilience in the context of sustainable development. The first recommendation emphasizes the importance of a policy that draws attention to the reciprocal relationship between the biosphere and the development of social welfare. The second one stresses the need for a policy that creates room for flexible and innovative collaboration oriented towards sustainability, and the third refers to the direction of a policy that makes sustainability operational in the context of socio-ecological resilience.

\section{Acknowledgement}

The author gratefully acknowledge the Ministry of Research, Technology and Higher Education Republic Indonesia for scholarship funding.

\section{Reference}

Adger, Neil W., (2000). Social and ecological resilience: are they related? Prog. Hum. Geogr., 24 (3), $347 \mathrm{e} 364$.

BPS (Statistics Indonesia), (2015). Statistik Kecamatan Karimunjawa, Jepara. Available online: http:/ / www.webcitation.org/6w6e2PL6C

BPS (Statistics Indonesia), (2016). Statistik Kecamatan Karimunjawa, Jepara. Available online: http:/ / www.webcitation.org/6w6ixWvT2

Baiquni, M., Damanik, J., Rindrasih, E. (Eds.) (2014). Ecotourism Destinations In Archipelago Countries. Gadjah Mada University Press. Yogyakarta.

Balai Taman Nasional Karimunjawa. (2004). Penataan Zonasi Taman Nasional Karimunjawa, Buku 


\section{Laporan TNKJ, Semarang.}

Briedenhann, J., Wickens, E., (2004). Tourism routes as a tool for the economic development of rural areas - vibrant hope or impossible dream?. Tourism Management, 25, 71-79. DOI: 10.1016/S0261-5177(03)00063-3.

Bryman, (2008). Social Research Methods, 3rd edn, Oxford University Press, New York.

Ca`noves, G., Villarino, M., Priestley, G.K., Blanco, A., (2004). Rural tourism in Spain: an analysis of recent evolution. Geoforum, 35 (6), 755-769. DOI: 10.1016/j.geoforum.2004.03.005.

Chiang, Y.-C., Tsai, F.-F., Chang, H.-P., Chen, C.-F., Huang, Y.-C., (2014). Adaptive society in a changing environment: Insight into the social resilience of a rural region of Taiwan. Land Use Policy, 36, 510-521. doi:10.1016/j.landusepol.2013.09.026

Cochrane, J. (2010). The Sphere of Tourism Resilience. Tourism Recreation Research, Vol. 35, No. 1, 173-185. DOI : 10.1080/02508281.2010.11081632

Dewi, S., Belcher, B., \& Puntodewo, A. (2005). Village economic opportunity, forest dependence, and rural livelihoods in East Kalimantan, Indonesia. World Development, 33(9), 1419-1434. https:/ / doi.org/10.1016/j.worlddev.2004.10.006

Euler, M., Krishna, V., Schwarze, S., Siregar, H., \& Qaim, M. (2017). Oil Palm Adoption, Household Welfare, and Nutrition Among Smallholder Farmers in Indonesia. World Development, 93 (Supplement C), 219-235. DOI: https://doi.org/10.1016/j.worlddev.2016.12.019

Hall, D., (2004). Rural tourism development in South-Eastern Europe: transition and the search for sustainability. International Journal of Tourism Research, 6, 165-176. DOI: 10.1002/jtr.482.

Hall, C., Jenkins, J., (1998). The Policy Dimensions of rural tourism and recreation. 1998. In: Butler, R., Hall, C., Jenkins, J. (Eds.), Tourism and Recreation in Rural Areas. Wiley, Chichester, pp. 19-42.

Harini, R., Susilo, B., Sarastika, T., Supriyati, S., Satriagasa, M. C., \& Ariani, R. D. (2017). The Survival Strategy of Households Affected by Tidal Floods: The Cases of Two Villages in the Pekalongan Coastal Area. Forum Geografi, 31(1), 163-175.

Holling, C.S., .L.H. Gunderson, (2002). Resilience and Adaptive Cycles. In: L.H. Gunderson \& C.S. Holling (eds) . Panarchy. Washington, DC: Island Press. P 25-26.

Kinsley, M., (2000). Economic Renewal Guide: A Collaborative Process for Sustainable Community Development. Rocky Mountain Institute, CO.

Krippendorff, K. (2004). Content Analysis: An Introduction to its Methodology (2nd Edition). Thousand Oaks. Sage Publications.

Long, P., Lane, B., (2000). Rural tourism development. 1999. In: Gartner, W., Lime, D. (Eds.), Trends in Outdoor Recreation, Leisure and Tourism. CABI, Wallingford, pp. 299-308.

MacDonald, R., Jolliffe, L., (2003). Cultural rural tourism: evidence from Canada. Annals of Tourism Research 30, pp. 307-322. DOI : 10.1016/S0160-7383(02)00061-0.

Mahdi, Shivakoti, G., \& Schmidt-Vogt, D. (2008). Chapter 3 - Livelihood Change and Livelihood Sustainability in the Uplands of Lembang Subwatershed, West Sumatra Province of Indonesia, in a Changing Natural Resources Management Context. In Redefining Diversity $\mathcal{E}$ Dynamics of Natural Resources Management in Asia, Volume 4 (pp. 19-43). Elsevier. https:/ / doi.org/10.1016/B978-0-12-805451-2.00003-X

Muganda, M., Sahli, M. and Smith, K. (2010). Tourism's contribution to poverty alleviation: a community perspective from Tanzania. Development Southern Africa, Vol. 27, No. 5, pp.629646. DOI : $10.1080 / 0376835 X .2010 .522826$

Neto, F. (2003). A New Approach to Sustainable Tourism Development: Moving Beyond 
Environmental Protection, DESA Discussion Paper No. 29, United Nations. Available online: http:/ / www.un.org/esa/esa03dp29.pdf

OECD, (1994). Tourism Strategies and Rural Development. OECD, Paris.

Perz, S.G., Cabrera, L., Carvalho, L.A., Castillo, J., Chacacanta, R., Cossio, R.E., Solano, Y.F., Hoelle, J., Perales, L.M., Puerta, I., Céspedes, D.R., Camacho, I.R., Silva, A.C., (2012). Regional integration and local change: road paving, community connectivity, and social-ecological resilience in a tri-national frontier, southwestern Amazonia. Regional Environmental Change,12, 35-53. DOI: 10.1007/ s10113-011-0233-x

Rijanta, R. (2005). Insularitas dan Keterbelakangan Ekonomi Wilayah menuju Model Konseptual Perkembangan Wilayah Pulau-Pulau Kecil di Indonesia. Majalah Geografi Indonesia, 19 (2). DOI: https:// doi.org/10.22146/mgi.13290 .

Immawati, R, Simbolon, D. Wiryawan, B. Murdiyanto, B., Wiji Nurani, T. (2012). Model Pengelolaan Perikanan karang di Taman Nasional Karimunjawa. Forum Pascasarjana, Vol. 35 No. 1 Januari 2012: 25-35

Rawluk, A., and A. Curtis. (2016). Reconciling contradictory narratives of landscape change using the adaptive cycle: a case study from southeastern Australia. Ecology and Society 21(1):17. http:/ / dx.doi.org/10.5751/ES-08245-210117

Jumadi \& Kuswaji D. P., (2005). Analysis of Susceptance Storey Level Damage of Coral Reefs in Territorial Water of Archipelago in Karimunjawa by Using Geographic Information System. Forum Geografi, 19 (1), pp. 67-80. DOI: 10.23917/forgeo.v19i1.4568.

Ritohardoyo, S. (2004). Influence of Private Forest Land to Farmers Welfare in Yogyakarta Special Province. Forum Geografi 13(2), DOI: https:/ / doi.org/10.23917/forgeo.v13i2.458

Setiawan, B., Rijanta, Baiquni. (2017). Poverty and Tourism: Strategies and Opportunities in Karimunjawa Island, Central Java. Journal of Indonesian Tourism and Development Studies, 5(2), pp. 121-130. DOI: 10.21776/ub.jitode.2017.005.02.08

Salvia, R., Quaranta, G., (2015). Adaptive Cycle as a Tool to Select Resilient Patterns of Rural Development. Sustainability 7, 11114-11138. DOI: 10.3390/su70811114

Sari, K., Amaliah, N., Rosha, B. C., \& Irawati, A. (2016). The Role of Built Environment on UnderFive Malnutrition in Indonesia. International Journal of Health and Medicine, 1(1), 5-9.

Slootweg, R., F. Vanclay, and M. van Schooten. (2001). Function evaluation as a framework for the integration of social and environmental impact assessment. Impact Assessment and Project Appraisal 19 (1):19-28, DOI: http:/ / dx.doi.org/10.3152/147154601781767186

Thompson, D. (2016). Community adaptations to environmental challenges under decentralized governance in southwestern Uruguay. Journal of Rural Studies, 43, pp. 71-82. DOI: http:/ / dx.doi.org/10.1016/j.jrurstud.2015.11.008.

Tourism Information Center Jepara, (2015). Available online: https://ticjepara.com/.

Tsao, C., Ni, C., (2016). Vulnerability, resilience, and the adaptive cycle in a crisis-prone tourism community. Tourism Geographies, 18, 80-105. DOI:10.1080/14616688.2015.1116600

UN, (2001). Sustainable development of tourism, Report of the Secretary-General (Document No. E/ CN.17/2001/PC/21), New York, UN.

Urry, J., (2002). The Tourist Gaze, second eds. Sage, London.

Walker, B., Holling, C. S., Carpenter, S, R. and Ann Kinzig, (2004). Resilience, Adaptability and Transformability in Social-ecological Systems, Ecology and Society, 9(2): 5. [online] URL: http:/ / www.ecologyandsociety.org/vol9/iss2/art5

Widianingsih, N. N., Theilade, I., \& Pouliot, M. (2016). Contribution of Forest Restoration to Rural 
Livelihoods and Household Income in Indonesia. Sustainability, 8(9), 835. DOI: https:/ / doi. org/10.3390/su8090835

Wijayanti, R., Baiquni, M., \& Harini, R. (2016). Livelihood Strategies as Responses to Water Availability in Pusur Subwatershed, Bengawan Solo. Forum Geografi, 30(2), 130-139.

Williams, K. J. H., and J. Schirmer. (2012). Understanding the relationship between social change and its impacts: the experience of rural land use change in southeastern Australia. Journal of Rural Studies 28(4):538-548. http:/ / dx.doi.org/10.1016/j.jrurstud.2012.05.002

Wilson, Geoff A., (2012). Community Resilience and Environmental Transitions. Routledge, NY.

World Economic Forum (WEF). (2013). Global Risk 2013, eight edition. Geneva: World Economic Forum. Online at http://reports.weforum.org/global-risks-2013/, accessed 21 February 2017.

Yang, L., (2015). Rural tourism and poverty alleviation: the case of Nujiang, Yunnan, China. International Journal Tourism Anthropology, 4 (4), pp. 343-362 DOI: 10.1504/IJTA.2015.074006. 